Joanna Petrykowska

\title{
WYBRANE ASPEKTY NOWOCZESNYCH FORM PROMOCJI
}

Zarys treści. Celem niniejszego opracowania jest przedstawienie wybranych nowoczesnych form promocji, takich jak marketing szeptany oraz marketing partyzancki, będących niestandardowymi, kreatywnymi rozwiązaniami, mającymi w sposób skuteczny przykuć uwagę odbiorcy.

Słow a kluc zow e : nowoczesne formy promocji, marketing partyzancki, marketing szeptany, marketing wirusowy.

\section{WSTĘP}

W dobie nasilającej się konkurencji, a także permanentnie wzrastających wymagań klientów, konieczne staje się całościowe, wybiegające w przyszłość, podejście przedsiębiorstwa do możliwości zaangażowania się w proces interakcji z licznymi uczestnikami rynku, zwłaszcza klientami, przy jednoczesnym uwzględnianiu ich potrzeb i preferencji oraz dostosowaniu się do ich wymagań. Gwałtowne przemiany, które zachodzą w gospodarce, zarówno światowej, jak i lokalnej, istotnie wpływają na sposób podejścia do promocji i na określenie jej podstawowych kierunków oraz reguł działania uwzględniających nowe trendy i perspektywiczne zmiany w złożonym otoczeniu. Typowe, konwencjonalne strategie promocyjne odnoszą coraz mniejsze efekty. Niezbędne jest więc poszukiwanie lepszych, bardziej skutecznych rozwiązań w pozyskiwaniu nowych nabywców. Oprócz poprawy jakości produktów, udoskonalenia obsługi klienta, a także wdrażania nowych, ciekawych produktów, szansą na wyróżnienie się jest tworzenie unikalnych bądź nietypowych strategii marketingowych, w tym promocyjnych, które dzięeki swojej wyjątkowości zdołają przyciągnąć uwagę 
odbiorcy. Celem opracowania jest przedstawienie wybranych, najbardziej popularnych form promocji, których zadaniem jest zwrócenie, w niestandardowy sposób, uwagi nabywców na promowany produkt i sprawienie, że zdecydują się na jego zakup.

\section{MARKETING SZEPTANY}

Jedną z niestandardowych form promocji jest marketing szeptany, który obecnie ma coraz więcej zwolenników z uwagi na fakt, że konsument jest najważniejszym źródłem opinii na temat różnych produktów. Informacje, jakie konsumenci uzyskują od innych osób - rodziny, przyjaciół, znajomych, są bardziej wiarygodne i mają w związku z tym dla nich zdecydowanie większą wartość. W trakcie rozmów prowadzonych na tematy związane z konkretną firmą bądź produktami przez nią oferowanymi zachodzi tak zwana komunikacja szeptana (Chrąchol, 2009). Istota marketingu szeptanego tkwi w rozmowach między ludźmi, którzy chcą w ten sposób wyrazić autentyczne zainteresowanie danym tematem. Komunikaty w marketingu szeptanym rozprzestrzeniają się, z uwagi na to, że ludzie lubią tworzyć i przekazywać różne historie, chcą również zwrócić na siebie uwagę innych, co jest możliwe tylko wówczas, gdy mają do powiedzenia coś interesującego bądź zabawnego, a zwłaszcza coś nowego (Hughes, 2008). Ponadto, prowadzenie rozmów może często wynikać z chęci nawiązywania kontaktów z innymi ludźmi czy znalezienia potwierdzenia dla swoich poglądów. Innym istotnym argumentem przemawiającym za chęcią prowadzenia rozmów może być poczucie dumy, wynikające z tego, że wybrało się daną markę, która została uznana wśród społeczeństwa za godną uwagi i polecenia, lub że dokonało się trafnego wyboru (Balter, Butman, 2007).

Marketing szeptany nazywany jest na wiele sposobów. W polskim nazewnictwie określany bywa jako: marketing ,z ust do ust”, ,szum medialny”, „szeptomarketing” (Hughes, 2008), „poczta pantoflowa” (Balter, Butman, 2007). Natomiast $\mathrm{w}$ terminologii angielskiej stosuje się dwa pojęcia: buzzmarkeing (od słowa buzz oznaczającego brzęczeć, buczeć) lub word-of-mouth marketing (WOMM), przy czym warto podkreślić, że pomimo tego, iż bardzo często pojęć tych używa się zamiennie, zdaniem praktyków marketingu należy je rozróżniać. Buzzmarketing kojarzony jest $\mathrm{z}$ wywołaniem szumu, rozgłosu, zainteresowania wobec marki, word-of-mouth marketing, natomiast $\mathrm{z}$ działaniami polegającymi na inicjowaniu naturalnych rekomendacji produktów przez konsumentów. Inaczej mówiąc, w buzzmarketingu do wywołania szumu marketingowego stosuje się podejście skierowane do konsumentów, natomiast w WOMM - podejście razem z konsumentem (Hughes, 2008). 
Różni autorzy interpretują również w odmienny sposób znaczenie marketingu szeptanego. Hughes (2008) twierdzi, że: „marketing szeptany porywa twoich klientów i media - wszyscy oni zaczynają uważać, że o twojej marce lub firmie warto mówić. Rozmawianie o niej zaczyna fascynować i staje się rozrywką".

$\mathrm{Z}$ kolei Balter i Butman, ujmując istotę pojęcia word of mouth (WOM), piszą między innymi: „wszyscy rozmawiają o produktach i usługach i robią to nieustannie. W WOM nie chodzi o wyłonienie maleńkiej podgrupy wpływowych i dobrze powiązanych osób, które mogłyby rozmawiać o produkcie czy usłudze. Nie chodzi o ekspertów, pasjonatów, wybitne osobistości czy ludzi posiadających wiedzę specjalistyczną. WOM dotyczy wszystkich ludzi”. Rosen (2003) natomiast twierdzi, że marketing szeptany to suma wszystkich komentarzy na temat danego produktu lub marki, wygłoszonych przez ludzi w danym okresie. Komentarze, czyli opinie, docierają do odbiorcy za pomocą różnych narzędzi, m.in. przez telefon, e-mail, kartkę papieru bądź przekaz ustny. Jedno łączy wszystkie te narzędzia - przekaz powstaje w mózgu nadawcy, a zostaje odebrany przez mózg odbiorcy. Interesującą definicję marketingu szeptanego przedstawili Jasielska i Maksymiuk (2010), podając, że polega on na przekazywaniu informacji o produkcie i kreowaniu zainteresowania nim w sposób nieformalny, z ust do ust, tzw. pocztę pantoflową przez np. rodzinę, przyjaciół, znajomych oraz inne osoby niezwiązane z producentem.

Do najważniejszych cech marketingu szeptanego zalicza się (Polkowska, 2011):

- komunikację „konsument do konsumenta”,

- dobrowolne rozmowy, nieopłacone opinie i rekomendacje,

- jawność relacji z marketerem.

Marketing szeptany angażuje klientów i media, wywołując w nich przekonanie o tym, że o firmie i jej produktach warto mówić, a rozmowy te zaczynają jednocześnie interesować i stawać się rozrywką. Tradycyjny model marketingu opiera się na sformułowaniu przekazu reklamowego i nadaniu go za pomocą odpowiednich środków reklamy potencjalnym klientom (masowym bądź indywidualnym) i na tym się kończy. Natomiast marketing szeptany poszerza ten proces o przekazanie przez potencjalnego klienta informacji dalej, swoim znajomym, którzy również powielą informację, przekazując ją innym (Hughes, 2008). Tak powstaje szum marketingowy wokół danego produktu lub marki.

Ogromne znaczenie w rozwoju marketingu szeptanego ma postęp technologiczny, dzięki któremu grupy odbiorców działań stosowanych w jego zakresie dynamicznie się rozwijają. Nowe technologie pozwalają błyskawicznie dotrzeć z przekazem do odbiorców za pomocą sms-ów, poczty e-mail, forów dyskusyjnych, blogów, portali społecznościowych, stron www czy innych metod udostępnianych przez Internet (Hughes, 2008). 
Przykładowe formy marketingu szeptanego zaprezentowano $\mathrm{w}$ tabeli 1 . Tworzenie szumu wśród ludzi oraz w mediach nie jest łatwym zadaniem i wymaga zastosowania dokładnie przemyślanych i zaplanowanych działań. Hughes (2008) podaje wskazówki na ten temat, które nazywa „sześcioma przyciskami szumu". Zdaniem tego autora są to zagadnienia, które dostarczone konsumentom sprawiają, że zaczynają o nich rozmawiać, gdyż zawsze przykuwają ich uwagę. Pierwszym z nich jest temat tabu, czyli zagadnienia, których zwykle publicznie się nie porusza, z uwagi na to, że są krępujące i nie wypada o nich rozmawiać, zawstydzają ludzi bądź wprawiają ich w zakłopotanie i dlatego właśnie wzbudzają ludzką ciekawość. Może być to humor związany z procesami fizjologicznymi człowieka, który wygłoszony publicznie zawstydza. Innym tematem tabu jest kłamstwo czy seks, o którym rozmowa z osobami z różnych środowisk czy pokoleń może wprawić w zakłopotanie.

Tabela 1. Przykładowe formy marketingu szeptanego

\begin{tabular}{|c|c|}
\hline Nazwa formy & Główne założenia \\
\hline Evangelist marketing & $\begin{array}{l}\text { polega na takim tworzeniu u klienta silnego zaufania i przekonania klienta co } \\
\text { do wyboru produktu, że staje się on ambasadorem marki i z własnej inicjatywy } \\
\text { zaczyna rekomendować ofertę innym nabywcom }\end{array}$ \\
\hline $\begin{array}{l}\text { Marketing wirusowy } \\
\text { (Viral marketing) }\end{array}$ & $\begin{array}{l}\text { polega na tworzeniu zabawnych bądź wyjątkowo interesujących komunikatów } \\
\text { w Internecie, które są zaprojektowane tak, by można je było w prosty sposób } \\
\text { przekazywać innym osobom; często mają formę e-mail, czy internetowego filmu; } \\
\text { proces rozprzestrzeniania się tych komunikatów jest analogiczny do replikacji } \\
\text { wirusów atakujących żywe komórki }\end{array}$ \\
\hline Brand blogging & $\begin{array}{l}\text { bazuje na wykorzystaniu potencjału blogów internetowych i uczestnictwie } \\
\text { w blogsferze, dzieleniu się ciekawymi informacjami tam umieszczanymi, co } \\
\text { w konsekwencji wywołuje rozmowy o produktach, wzbudzając zainteresowanie nimi }\end{array}$ \\
\hline Community marketing & $\begin{array}{l}\text { polega na to tworzeniu i wspieraniu niszowych społeczności zainteresowanych } \\
\text { daną marką czy produktem, głównie poprzez tworzenie klubów i forów } \\
\text { dyskusyjnych }\end{array}$ \\
\hline Product seeding & $\begin{array}{l}\text { polega na przekazywaniu do testowania produktów lub próbek wpływowym } \\
\text { osobom, które rozpowszechniają na ich temat pozytywne informacje }\end{array}$ \\
\hline Causa marketing & $\begin{array}{l}\text { polega na wspieraniu kwestii społecznych w celu zdobycia szacunku i wsparcia } \\
\text { ludzi uznających dany problem za istotny }\end{array}$ \\
\hline Trendsetting & $\begin{array}{l}\text { polega na rozpowszechnianiu mody, kreowaniu trendów, na pewne marki czy } \\
\text { produkty, przez odpowiednio wybrane osoby w społeczeństwie; trendsetterzy } \\
\text { to najczęściej osoby młode, atrakcyjne, charakteryzujące się dużym uznaniem } \\
\text { w towarzystwie; są lubiane i podziwiane; ich mocną stroną jest przebojowość } \\
\text { i wyczucie smaku; poprzez prezentowane przez siebie postawy, zachowania, style } \\
\text { są liderami opinii i wzorami do naśladowania }\end{array}$ \\
\hline Casual $\mathrm{m}$ & $\begin{array}{l}\text { polega na wykorzystaniu promocji jednego produktu do równoległej rekomendacji } \\
\text { innych, niezwiązanych z głównym celem działań }\end{array}$ \\
\hline
\end{tabular}

Źródło: opracowanie własne na podstawie: http://wiadomosci.mediarun.pl/artykul/marketing-marketing (21.11.2011) oraz http://pl.wikipedia.org/wiki/Buzz_marketing (21.11.2011). 
Kolejnym „przyciskiem szumu” jest niezwykłość, czyli treści o wyróżniającym się charakterze, które dotąd jeszcze nie były poruszane. Oburzenie jest następnym sposobem na wywołanie szumu. W tym przypadku chodzi o zainicjowanie działania mającego na celu wywoływanie wzburzenia czy irytacji innych ludzi w celu wywołania rozmowy. Należy pamiętać jednak o tym, że działania te powinny być $\mathrm{w}$ jakiś sposób związane $\mathrm{z}$ daną marką czy produktem po to, żeby ludzie mogli łatwiej skojarzyć nadawcę komunikatu i mówić również o nim, a nie tylko o skandalicznym wydarzeniu. Komizm to „przycisk szumu”, który może w dużym stopniu wpłynąć na konsumentów, z uwagi na to, że dokładnie i wszechstronnie przemyślane działania uwzględniające ten aspekt mogą rozbawić odbiorów, wzbudzić ich ciekawość i stworzyć doskonały pretekst do rozmów. Komizm jest jednak trudniejszy do zastosowania niż większość pozostałych zagadnień. Dodatkowo, jeśli starania w byciu zabawnym się nie powiodą, mogą zadziałać na niekorzyść nadawcy i przynieść odwrotny skutek. Istnieje również „przycisk przypominania”, którego można używać w celu wzmocnienia efektu szumu wywołanego przez początkowe działania promocyjne, na przykład reklamę tradycyjną. Wykorzystywane są w tym przypadku dodatkowe zabiegi marketingowe z użyciem takich samych motywów przewodnich, jak w pierwotnych działaniach, aby klienci mogli skojarzyć podobieństwo i zacząć rozmawiać o danym produkcie. Ostatnim z omawianych zagadnień jest „przycisk tajemnicy", który polega na wyjawieniu poufnej informacji, która ma na celu wywołanie dyskusji na dany temat. Skuteczność tego rozwiązania może wynikać z tego, że ludzie uwielbiają rozmawiać o tematach objętych tajemnicą, których nie mogą zdobyć zbyt łatwo, a gdy już poznają tajemnicę, czują się wyróżnieni ze względu na zaufanie, jakim zostali obdarzeni przez osobę ujawniającą sekret (Hughes, 2008).

Niezwykle ważnym sposobem przyciągania uwagi w marketingu szeptanym jest wykorzystanie osób, które mogą mieć istotny wpływ na powstawanie i kreowanie szumu marketingowego, tak zwanych liderów opinii (influencers ${ }^{1}$ ). Osoby te, z uwagi na to, że mają charyzmę i łatwość nawiązywania kontaktów z innymi, stają się liderami opinii wśród społeczności i traktowane są jako godne zaufania oraz zostają uznane za ekspertów w swojej dziedzinie lub doradców, dzięki wiedzy, jaką mają na dany temat i szczególnemu zainteresowaniu w tym zakresie. Liderami opinii mogą być również osoby publiczne (gwiazdy masowej kultury, politycy), które za pośrednictwem różnego rodzaju mediów docierają do szerokiej grupy odbiorców i stają się dla nich autorytetem. Liderzy opinii z reguły jako pierwsi sięgają po nowinki i z własnej potrzeby dążą do poszerzania wiedzy na ich temat (Rosen, 2003).

\footnotetext{
Od angielskiego słowa influence, co oznacza: wpływ, oddziatywanie.
} 
Warto podkreślić, że skuteczność marketingu szeptanego zależy w dużym stopniu od odpowiedniego otoczenia, w którym podsuwane będą tematy do rozmów. Miejsce takie powinno skupiać właściwą grupę docelową dla promowanego produktu, czyli środowisko, które chętnie będzie podejmowało rozmowy na dany temat we własnym kręgu. Istotne jest, aby móc przeniknąć $\mathrm{w}$ to środowisko w sposób naturalny, umożliwiający upodobnienie się do jego uczestników, w celu uzyskania możliwości dostępu do opinii z pierwszej ręki i skutecznego komunikowania się z nimi (Rosen, 2003). Należy jednak pamiętać o tym, że przekazywanie komunikatu nie powinno ograniczać się wyłącznie do grupy docelowej. Działania promocyjne powinny bowiem również docierać do osób niezwiązanych bezpośrednio z danym produktem, ale mogących przekazać swoje rekomendacje innym, spełniającym kryteria, docelowym klientom (Hughes, 2008).

\section{MARKETING PARTYZANCKI}

Kolejną z form uwzględniających zastosowanie nowych rozwiązań w promocji jest marketing partyzancki, który uznawany jest za skuteczny i coraz bardziej popularny sposób służący zdobywaniu uwagi klientów. Istotnymi czynnikami efektywnego marketingu partyzanckiego jest element zaskoczenia odbiorcy, a także wiedza marketingowa, jaką przedsiębiorstwo powinno zdobyć w celu podjęcia odpowiednich działań (Murdoch, 2003).

Podobnie jak w przypadku marketingu szeptanego ta forma promocji jest różnie określana $\mathrm{w}$ teorii $\mathrm{i}$ praktyce. Zamiennie $\mathrm{z}$ marketingiem partyzanckim stosuje się nazwę reklamy partyzanckiej, a także pochodzące $\mathrm{z}$ języka angielskiego guerrilla marketing - wywodzi się od znaczenia słowa partyzant i analogicznie do jego sposobu walki lub też oporu, odnosi się do nieszablonowych, zaskakujących, ale czasem również podstępnych metod promocyjnego działania (Murdoch, 2003).

W literaturze przedmiotu autorzy licznych publikacji odmiennie również definiują marketing partyzancki. Sutherland i Canwell (2008) piszą między innymi, że ,ten rodzaj technik marketingowych polega na działaniach niekonwencjonalnych, zaplanowanych w celu maksymalizacji ich skutków przy wykorzystaniu skąpych zasobów”. Z kolei Murdoch (2003) podaje, że są to „twórcze, niekonwencjonalne sposoby reklamowania, stosowane na ogół w sytuacjach, w których zawodzi tradycyjne podejście albo jest ono nielegalne lub niedostępne".

Istotą guerrilla marketing są więc nietuzinkowe działania marketingowe, które mają na celu uzyskanie najlepszych wyników przy niskich zasobach. Przy czym wykorzystuje się w jego ramach środowisko naturalne docelowej grupy 
odbiorców, natomiast udział tradycyjnych mediów jest pomijany. Często czynności przeprowadzane są w taki sposób, że odbiorcy określonych działań nie są świadomi tego, iż stosowane są wobec nich działania promocyjne. Brak przekonania odnośnie do celowości działań określonej firmy oraz naturalność formy przekazu przyczyniają się do wzrostu jego wiarygodności, a także ograniczają efekt jego odrzucenia. Osoby odpowiedzialne za realizację określonych działań rozdzielane są na mniejsze zespoły i samodzielnie wykonują powierzone im zadania na niewielkich obszarach, unikając przy tym bezpośredniej walki z konkurentami (Smalec, 2010).

Do najbardziej istotnych cech, odróżniających ten rodzaj marketingu od marketingu w tradycyjnym rozumieniu, zaliczyć można (Zięba, 2010):

- inwestowanie w komunikację czasu, energii i wyobraźni, która jednocześnie w jak najmniejszym stopniu powinna pociągać za sobą koszty finansowe,

- $\quad$ wykorzystywanie w szczególności psychologii, a w mniejszym stopniu doświadczeń i spekulacji,

- budowanie długotrwałych relacji, a nie okresowe zwiększenie sprzedaży,

- łączenie różnych mediów i środków wyrazu,

- $\quad$ wsparcie ze strony nowych technologii.

Metody partyzanckiego marketingu coraz częściej wiązane są z możliwościami, jakie dają ambient media, wywodzące się z klasycznych form reklamy zewnętrznej, które jednak dalece wykraczają poza jego ramy poprzez stosowanie kreatywnych rozwiązań (Smalec, 2010). Za ambient media uważane są niestandardowe formy komunikacji marketingowej, które wykorzystują nietypową lokalizację na elementach przestrzeni publicznej, a także posługują się niezwykłą metodą wykonania, przy jednoczesnym zastosowaniu wszelkich możliwych metod przykuwania uwagi odbiorców (Kaniewska-Sęba, 2008). Są to media niszowe, które podobnie jak marketing partyzancki, wykorzystują efekt nowości oraz niestandardowe kanały komunikacji z odbiorcami. Główna różnica pomiędzy marketingiem partyzanckim a marketingiem ambientowym tkwi w nośniku komunikatu marketingowego. Ambientowe instalacje wyróżniają się zwykle widocznym logo firmy, umieszczanym na ich powierzchni, hasłami reklamowymi, bądź też samym produktem, jednocześnie najczęściej cechują się nienaturalną wielkością. Mogą to być oryginalne konstrukcje i formy umieszczane na budynkach, ulicach, pojazdach (Dołhasz, 2009). Natomiast guerrilla marketing stosowany jest jako pewien dwuznacznik czy zagadka, która ma zaintrygować klienta, lecz bez zbędnego przytłaczania typową treścią reklamowego przekazu (Smalec, 2010).

Do najważniejszy powodów, dla których marketing partyzancki ma obecnie tak duże zapotrzebowanie, zaliczyć można (Levinson, 1998): 
- rosnącą rolę małych przedsiębiorstw, których coraz więcej przybywa w wyniku procesów decentralizacji w sektorze wielkich korporacji,

- rozluźnienie przepisów prawnych w licznych państwach,

- swobodny dostęp do nowoczesnych technologii,

- niewielką świadomość, a także brak zrozumienia marketingu przez małe przedsiębiorstwa, w których problemem jest również brak środków pieniężnych przeznaczanych na marketing,

- prostota we wprowadzeniu oraz łatwość w odbiorze,

- $\quad$ niski koszt działań partyzanckich, w które trzeba zainwestować.

Podsumowując, można stwierdzić, że marketing partyzancki wykorzystuje w głównej mierze niekonwencjonalne i oryginalne metody oraz środki przekazywania informacji i komunikatów promocyjnych. Skupia się głównie na przyciągnięciu uwagi odbiorców, nawet w sytuacji, gdy treść danego komunikatu jest kontrowersyjna lub prowokacyjna. Wykorzystuje różne formy oddziaływania na odbiorców, które stosowane są w nietypowy sposób i przy stosunkowo niewielkich nakładach finansowych.

\section{PODSUMOWANIE}

W dzisiejszych czasach konsumenci są wyjątkowo niewrażliwi na sugestie reklamodawców stosowane w ramach tradycyjnych form, dlatego niezwykle istotne jest poszukiwanie nowatorskich rozwiązań, będących w stanie zaskoczyć odbiorców i przyciągnąć tym samym ich uwagę. Zarówno marketing szeptany, jak i marketing partyzancki stanowią nowoczesne, szybko rozwijające się formy promocji, które wykraczają poza ramy tradycyjnego marketingu. Wykorzystują bowiem działania i techniki, które odbiegają od tych stosowanych w klasycznej formie promocji. Marketing szeptany opiera się głównie na przekazach zawierających atrakcyjną historię związaną z danym produktem, która sprawia, że odbiorcy przekazu zaczynają ją rozpowszechniać. Aby wzbudzić zainteresowanie odbiorców i wywołać duży szum medialny, najkorzystniej jest zastosować jeden ze sprawdzonych motywów lub kilka z nich jednocześnie. Do najczęściej wykorzystywanych zalicza się tematy tabu, odwoływanie się do zagadnień niezwykłych, oburzających czy komicznych, a także poruszające wątek przypominania albo tajemnicy. Wystarczy podsunąć interesujący, ale trafnie określony i zdefiniowany temat do rozmów, aby doszło do komunikacji szeptanej. Marketing partyzancki z kolei wykorzystuje niekonwencjonalne, oryginalne metody i środki przekazu oraz opiera się głównie na dobrej znajomości psychiki ludzkiej, a jego najistotniejsze inwestycje to poświęcony czas, energia, jak również ludzka wyobraźnia, a nie pieniądze. Wymaga zatem pomysłowości, kreatywności oraz dużego 
zaangażowania i wysiłku autorów w tworzeniu niebanalnych kampanii marketingowych. Warto jednocześnie podkreślić, że obie opisane formy promocji realizowane są przy ponoszeniu relatywnie niskich środków finansowych w dotarciu do grupy docelowej, jak również poza jej granice, poprzez dobrze opracowany i atrakcyjny przekaz.

\section{LITERATURA}

Chrąchol U. (2009), Marketing szeptany jako efektywny sposób kreowania marki wśród konsumentów, [w:] Marketing przyszłości. Trendy. Strategie. Instrumenty. Wspótczesne wyzwania komunikacji marketingowej, G. Rosa, A. Smalec (red.), „Zeszyty Naukowe Uniwersytetu Szczecińskiego” nr 559, Ekonomiczne Problemy Usług $\mathrm{nr}$ 42, Szczecin.

Balter D., Butman J. (2007), Poczta pantoflowa: sztuka marketingu szeptanego, HELION, Gliwice.

Dołhasz M. (2009), Reklama ambientowa - nowa forma komunikacji marketingowej przedsiębiorstw, [w:] Marketing przyszłości. Trendy. Strategie. Instrumenty, Wspótczesne wyzwania komunikacji marketingowej, G. Rosa, A. Smalec (red.), „Zeszyty Naukowe Uniwersytetu Szczecińskiego” nr 559, Ekonomiczne Problemy Usług $\mathrm{nr}$ 42, Szczecin.

Hughes M. (2008), Marketing szeptany. $Z$ ust do ust. Jak robić szum medialny wokót siebie, firmy, produktu, MT Biznes, Warszawa.

Jasielska A., Maksymiuk R. A. (2010), Dorośli reklamuja, dzieci kupują. Kindermarketing i psychologia, Wydawnictwo Naukowe Scholar, Warszawa.

Kaniewska-Sęba, A. (2008), Ambient media jako nowoczesny instrument komunikacji, [w:] Marketing - zagadnienia współczesne, H. Mruk (red.), Wydawnictwo Forum Naukowe, Poznań.

Levinson J. C. (1998), Marketing partyzancki, PWE, Warszawa.

Murdoch A. (2003), Kreatywność w reklamie, Wydawnictwo Naukowe PWN, Warszawa.

Polkowska D. (2011), Social shoping jako narzędzie marketing szeptanego online, [w:] Marketing przyszłości. Tredny. Strategie. Instrumenty. Marketing $w$ działalności podmiotów rynkowych, G. Rosa, A. Smalec (red.), „Zeszyty Naukowe Uniwersytetu Szczecińskiego" nr 662, Ekonomiczne Problemy usług nr 74, Szczecin.

Rosen E. (2003), Fama. Anatomia marketingu szeptanego, Media Rodzina, Poznań.

Smalec A. (2010), Nowe formy komunikacji marketingowej - wybrane aspekty, [w:] Komunikacja rynkowa. Ewolucja, wyzwania, szanse, B. Pilarczyk, Z. Waskowski (red.), „Zeszyty Naukowe Uniwersytetu Ekonomicznego w Poznaniu” nr 135, Poznań.

Sutherland J., Canwell D. (2008), Klucz do marketingu. Najważniejsze teorie, pojęcia, postaci, Wydawnictwo Naukowe PWN, Warszawa.

Zięba K. (2010), Marketing partyzancki jako efektywna forma docierania do młodego konsumenta, [w:] Marketing $w$ realiach współczesnego rynku. Implikacje otoczenia rynkowego, Sz. Figiel (red.), PWE, Warszawa. 


\section{SELECTED ASPECTS OF MODERN FORM OF PROMOTION}

A bstract: Goal of this study is to show selected, modern forms of promotion, such as word mouth marketing and guerilla marketing, being out-of-line, creative solutions, riveting attention of an audience in effective way.

K e y w o r d s : new form of promotion, guerilla marketing, word mouth marketing. 